\title{
Effect of Water Losses by Evaporation and Chemical Reaction in an Industrial Slaker Reactor
}

\author{
Ricardo Andreola ${ }^{1}$, Osvaldo Vieira ${ }^{2}$, Onélia Aparecida Andreo dos Santos ${ }^{1}$ and Luiz Mario \\ de Matos Jorge ${ }^{1 *}$
}

${ }^{1}$ Departamento de Engenharia Química; Universidade Estadual de Maringá; Av. Colombo, 5790 - Bloco D90; lmmj@deq.uem.br, 87020-900; Maringá - PR - Brasil. ${ }^{2}$ Klabin Paraná Papéis; Fazenda Monte Alegre; Bairro Harmonia; 84275-000; Telêmaco Borba - PR - Brasil

\begin{abstract}
A dynamic model of the slaker reactor was developed and validated for Klabin Paraná Papéis causticizing system, responsable for white liquor generation used by the plant. The model considered water losses by evaporation and chemical reaction. The model showed a good agreement with the industrial plant measures of active alkali, total titratable alkali and temperature, without the need of adjustment of any parameter. The simulated results showed that the water consumption by the slaking reaction and evaporation exerted significant influence on the volumetric flow rate of limed liquor, which imposed a decrease of $4.6 \%$ in the amount of water in reactor outlet.
\end{abstract}

Key words: Slaker reactor, modeling and simulation, white liquor

\section{INTRODUCTION}

The causticizing reactor system from Klabin Paraná Papéis produce white liquor used in cellulose digesters. This system is composed by one slaker reactor followed by nine causticizing reactors in sequence. According to Fig. 1, green liquor and lime are continuously introduced in the stirred slaker reactor. The lime from lime kiln is mainly composed of a large quantity of calcium oxide and a small amount of inert solids.

The calcium oxide instantaneously reacts with water from green liquor producing calcium hydroxide, according to a highly exothermic reaction, called slaking reaction: $\mathrm{CaO}_{(\mathrm{s})}+\mathrm{H}_{2} \mathrm{O}_{(\mathrm{l})}$
$\mathrm{Ca}(\mathrm{OH})_{2(\mathrm{~s})}$. In turn, green liquor is a liquid solution with a large quantity of sodium carbonate that reacts with calcium hydroxide producing sodium hydroxide and calcium carbonate, according to the causticizing reaction: $\mathrm{Na}_{2} \mathrm{CO}_{3(\mathrm{aq})}+\mathrm{Ca}(\mathrm{OH})_{2(\mathrm{~s})} \rightarrow 2$ $\mathrm{NaOH}_{(\mathrm{aq})}+\mathrm{CaCO}_{3(\mathrm{~s})}$. This reaction is slightly exothermic.

At the outlet of the slaker reactor, there are two distinct streams: limed liquor and grits. The limed liquor is basically formed by a sodium hydroxide solution with calcium carbonate, calcium hydroxide, inert solids and eventually unreacted calcium oxide in suspension.

\footnotetext{
* Author for correspondence
} 


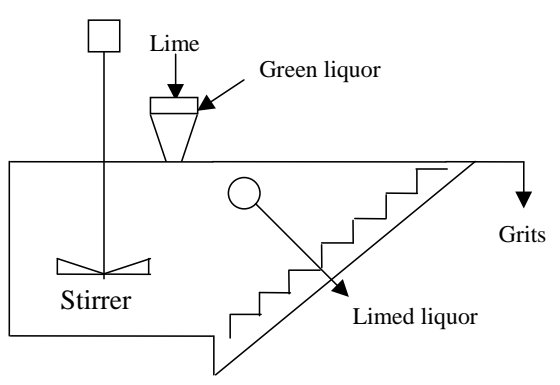

Figure 1 - Scheme of slaker reactor

In the sequence, the flow is fed in causticizing reactors by gravity, while the grits are removed from the reactor by a screw.

The main objective of this article was evaluate the effect of water losses by evaporation and chemical reaction in Klabin Paraná Papéis slaking reactor.

\section{MATERIAL AND METHODS}

\section{Mathematical Modeling}

The mathematical model was developed by Andreola (2001) from mass balances on each component, Equations (1) to (7), and from energy balance, Equation (9), over the slaker reactor, considering perfect mixture and constant volume. The hypothesis of perfect mixture was based on the research developed by Hypponen and Luuko (1984) that showed the same value of residence time distribution for solids and liquid in a causticizing reactor system. The assumption of constant volume $(\mathrm{V})$ was based on the fact that the volume of slaker reactor was constant. The salker reactor has an outlet for the liquor at the top of reactor, according to Fig. 1, that keeps the level of liquid constant.

$$
\begin{aligned}
& \frac{d C_{a}^{*}}{d t}=\frac{1}{V}\left(q_{0} C_{a, 0}-q C_{a}^{*}\right)-r_{1}\left(\frac{P M_{a}}{P M_{N a_{2} O}}\right) \\
& \frac{d C_{b}^{*}}{d t}=\frac{1}{V}\left(q_{0} C_{b, 0}-q C_{b}^{*}\right)+2 r_{1}\left(\frac{P M_{b}}{P M_{N a_{2} O}}\right) \\
& \frac{d C_{c}^{*}}{d t}=\frac{1}{V}\left(q_{0} C_{c, 0}-q C_{c}^{*}\right) \\
& \frac{d m_{d}}{d t}=w_{d, 0}-\frac{m_{d} q}{V}-V r_{2}
\end{aligned}
$$

$$
\begin{aligned}
& \frac{d m_{e}}{d t}=w_{e, 0}-\frac{m_{e} q}{V}-V\left(\frac{P M_{e}}{P M_{\mathrm{Na}_{2} \mathrm{O}}}\right) r_{1}+V\left(\frac{P M_{e}}{P M_{d}}\right) r_{2} \\
& \frac{d m_{f}}{d t}=w_{f, 0}-\frac{m_{f} q}{V}+V\left(\frac{P M_{f}}{P M_{N a_{2} \mathrm{O}}}\right) r_{1} \\
& \frac{d m_{g}}{d t}=w_{g, 0}-\frac{m_{g} q}{V}
\end{aligned}
$$

Where: $\mathrm{a}=\mathrm{Na}_{2} \mathrm{CO}_{3}, \mathrm{~b}=\mathrm{NaOH}, \mathrm{c}=\mathrm{Na}_{2} \mathrm{~S}, \mathrm{~d}=$ $\mathrm{CaO}, \mathrm{e}=\mathrm{Ca}(\mathrm{OH})_{2}, \mathrm{f}=\mathrm{CaCO}_{3}, \mathrm{~g}=$ inert solids.

The model predicted the actual concentration of each soluble component $\left(\mathrm{C}_{\mathrm{i}}{ }^{*}, \mathrm{i}=\mathrm{a}, \mathrm{b}, \mathrm{c}\right)$; the mass of insoluble solids inside the reactor $\left(m_{j}, j=d, e, f\right.$, $\mathrm{g}$ ) and the reactor's temperature $(\mathrm{T})$. Volumetric flow rate (q) and mass flow rates $\left(\mathrm{w}_{\mathrm{j}}\right)$ must be known. For model purposes, Causticising $\left(\mathrm{r}_{2}\right)$ and Slaking $\left(r_{1}\right)$ kinetics were corrected by molecular weights (PM) ratios.

The actual concentration of a generic component $i$ $\left(\mathrm{C}_{\mathrm{i}}\right)$ was determined from its apparent concentration $\left(\mathrm{C}_{\mathrm{i}}^{*}\right)$, using Equation (8). This procedure was necessary because the apparent concentration represented the mass of a specific component dissolved per unit volume of reactor. However, part of this volume was occupied by insoluble solids: $\mathrm{CaCO}_{3}, \mathrm{CaO}, \mathrm{Ca}(\mathrm{OH})_{2}$ and inert solids. Each volume of the solid compounds $\left(V_{j}=m_{j} / \rho_{j}, \mathrm{j}=d, e, f, g\right.$ ) must be subtracted from the total volume $(\mathrm{V})$ to obtain the effective volume $(\mathrm{Vr})$ and the real concentration of each component, Equation 8.

$$
C_{i}=C_{i}^{*} \cdot\left(\frac{V}{V r}\right)
$$


Where: $V r=V-\left(\frac{m_{f}}{\rho_{f}}+\frac{m_{e}}{\rho_{e}}+\frac{m_{d}}{\rho_{d}}+\frac{m_{g}}{\rho_{g}}\right)$

The operational reactor temperature was very close to the boiling temperature of the reacting mixture. Both reactions were exothermic and the reacting mixture temperature increased until it reached the boiling point. Consequently, there was energy loss by evaporation. To take this energy loss into account, this loss was included in Equation (9), admitting that the enthalpy and boiling temperature $\left(\mathrm{T}_{\mathrm{eb}}\right)$ of the solution were identical to that of pure water $\left(\Delta \mathrm{H}_{\text {evap }}\right)$ at the same pressure, because the reacting mixture was composed of a diluted solution. Insoluble solids were dispersed in solution and jointly form a slurry that had distinct density $\left(\rho_{\text {slurry }}\right)$ and heat capacity $\left(\mathrm{Cp}_{\text {slurry }}\right)$. The reactor's liquid phase was called liquor. Liquid $\left(\Delta \mathrm{H}_{\text {liquor }}\right)$ and solid $\left(\Delta \mathrm{H}_{\text {solids }}\right)$ enthalpy changes were evaluated from heat capacities of solids $\left(\mathrm{Cp}_{\mathrm{j}}\right)$ and dissolved compounds $\left(\mathrm{Cp}_{\mathrm{j}}\right)$.

$$
\frac{d T}{d t}=C_{1}-q_{\text {evap }} C_{2}
$$

Where:

$$
\begin{aligned}
& C_{1}=\frac{\left(\Delta H_{\text {liquor }}+\Delta H_{\text {solids }}+Q_{1}+Q_{2}-Q_{3}\right)}{V \rho_{\text {slurry }} C p_{\text {slurry }}} \\
& Q_{1}=\left(-\Delta H_{r 1}\right) V r_{1} ; Q_{2}=\left(-\Delta H_{r 2}\right) V r_{2} ; Q_{3}=U A\left(T-T_{a m b}\right) \\
& \Delta H_{\text {liquor }}=C p_{G L}\left[\left(C_{a, 0}^{*}+C_{b, 0}^{*}+C_{b, 0}^{*}\right) q_{0} \Delta_{1} \quad ;\right. \\
& \left.-\left(C_{a}^{*}+C_{b}^{*}+C_{c}^{*}\right) q \Delta_{2}\right] \text {; } \\
& \Delta H_{\text {solids }}=C p_{d}\left[\left(\frac{m_{d, 0} q_{0}}{V}\right) \Delta_{1}-\left(\frac{m_{d} q}{V}\right) \Delta_{2}\right]+ \\
& C p_{e}\left[\left(\frac{m_{e, 0} q_{0}}{V}\right) \Delta_{1}-\left(\frac{m_{e} q}{V}\right) \Delta_{2}\right]+ \\
& C p_{f}\left[\left(\frac{m_{f, 0} q_{0}}{V}\right) \Delta_{1}-\left(\frac{m_{f} q}{V}\right) \Delta_{2}\right]+ \\
& C p_{g}\left[\left(\frac{m_{g, 0} q_{0}}{V}\right) \Delta_{1}-\left(\frac{m_{g} q}{V}\right) \Delta_{2}\right] \text {; } \\
& \Delta_{1}=\left(T_{i n}-T_{r e f}\right) ; \Delta_{2}=\left(T-T_{\text {ref }}\right) ; \\
& C_{2}=\frac{\rho_{H 2 O} \Delta H_{\text {evap }}}{V \rho_{\text {slurry }} C p_{\text {slurry }}} \text {. }
\end{aligned}
$$

While the reactor temperature (T) was lower than the boiling temperature of the reacting mixture $\left(T_{e b}\right)$, water evaporation did not occur, therefore, $\mathrm{q}_{\text {evap }}=0$. However, when the reactor temperature reached $T_{e b}$, water evaporation occured at constant temperature and the rate of evaporation could be instantaneously evaluated from the solution of the following equation:

$\mathrm{C}_{1}-\mathrm{q}_{\mathrm{evap}} \mathrm{C}_{2}=0$.

As mentioned previously, the limed liquor was composed of an aqueous solution of sodium hydroxide, calcium carbonate, calcium hydroxide, inert solids and, eventually, calcium oxide unreacted. Consequently, the volumetric flow rate of limed liquor (q) was composed of five distinct terms: water $\left(\mathrm{q}_{\mathrm{H} 2 \mathrm{O}}\right)$; calcium carbonate $\left(\mathrm{q}_{\mathrm{CaCO} 3}\right)$; calcium hydroxide $\left(\mathrm{q}_{\mathrm{Ca}(\mathrm{OH}) 2}\right)$; inert solids $\left(\mathrm{q}_{\text {inerts }}\right)$ and calcium oxide $\left(\mathrm{q}_{\mathrm{CaO}}\right)$, according to Equation (10).

$$
q=q_{\mathrm{H} 2 \mathrm{O}}+q_{\mathrm{CaCO}_{3}}+q_{\mathrm{Ca}(\mathrm{OH}) 2}+q_{\mathrm{CaO}}+q_{\text {inerts }}
$$

Where:

$$
\begin{aligned}
q_{\mathrm{CaCO}_{3}} & =q\left(\frac{m_{f}}{V \rho_{f}}\right) ; q_{\mathrm{Ca}(\mathrm{OH}) 2}=q\left(\frac{m_{e}}{V \rho_{e}}\right) ; \\
q_{\mathrm{CaO}} & =q\left(\frac{m_{d}}{V \rho_{d}}\right) ; q_{\text {inerts }}=q\left(\frac{m_{g}}{V \rho_{g}}\right) .
\end{aligned}
$$

The volumetric water flow rate $\left(\mathrm{q}_{\mathrm{H} 2 \mathrm{O}}\right)$ could be obtained from water mass balance, admitting unsteady-state behavior, where the consumption of water was given by the slaking reaction $\left(\mathrm{q}_{\mathrm{r} 1}\right)$ and by evaporation ( $\mathrm{q}_{\text {evap}}$ ), according to Equation (11).

$$
\begin{aligned}
& q_{\mathrm{H} 2 \mathrm{O}}=q_{0}-q_{r^{2}}-q_{\text {evap }} \\
& \text { Where: } q_{r 2}=\frac{r_{2} V}{\rho_{\mathrm{H}_{2} \mathrm{O}}}\left(\frac{P M_{\mathrm{H}_{2} \mathrm{O}}}{\mathrm{PM}_{\mathrm{Na}_{2} \mathrm{O}}}\right)
\end{aligned}
$$

The volumetric flow rate of limed liquor, q, could be obtained from Equations (10) and (11), according to Equation (12).

$$
q=\left(\frac{V}{V r}\right)\left(q_{0}-q_{r 2}-q_{\text {evap }}\right)
$$

The reaction rate equations for the slaking reaction $\left(\mathrm{r}_{2}\right), \mathrm{CaO}_{(\mathrm{s})}+\mathrm{H}_{2} \mathrm{O}_{(\mathrm{l})} \rightarrow \mathrm{Ca}(\mathrm{OH})_{2(\mathrm{~s})}$, and causticizing reaction $\left(\mathrm{r}_{1}\right), \mathrm{Na}_{2} \mathrm{CO}_{3(\mathrm{aq})}+\mathrm{Ca}(\mathrm{OH})_{2(\mathrm{~s})} 2 \mathrm{NaOH}_{(\mathrm{aq})}+$ 
$\mathrm{CaCO}_{3(\mathrm{~s})}$, employed in this work were those employed by Swanda (1994), given by Equations (13) and (14). Both reactions were exotheric and it took account in the model by heats of slaking $\left(\Delta \mathrm{H}_{\mathrm{r} 2}\right)$ and causticizing $\left(\Delta \mathrm{H}_{\mathrm{r} 1}\right)$ reactions.

$$
\begin{aligned}
& r_{2}=k_{2}\left(\frac{m_{d}}{V}\right) \\
& r_{1}=M_{1} C_{a, o}\left(\frac{m_{e}}{V}\right)\left\{k_{1} C_{a} M_{1}-k_{1^{\prime}}[E A]^{2}\right\} \\
& k_{1}=k_{1,0} \exp \left[-0.095 \Delta_{3}-27190 / R T\right] ; \\
& k_{1^{\prime}}=k_{2,0} \exp \left[-0.0604 \Delta_{3}-23004.14 / R T\right] ; \\
& T T A=C_{a} M_{1}+C_{b} M_{2}+C_{c} M_{3} ; \\
& E A=C_{b} M_{2}+0,5 C_{c} M_{3} ; \\
& \Delta_{3}=T T A-112.33 ; \\
& M_{1}=\frac{P M_{N a_{2} O}}{P M_{a}} ; M_{2}=\frac{P M_{N a_{2} O}}{P M_{b}} ; M_{3}=\frac{P M_{N a_{2} O}}{P M_{c}}
\end{aligned}
$$

\section{Parameters Evaluation}

The dynamic model had one thermal parameter $\mathrm{U}$, and three kinetic parameters: $\mathrm{k}_{2}, \mathrm{k}_{1,0}$ e $\mathrm{k}_{2,0}$. In this work, the overall heat transfer coefficient $\mathrm{U}$ was obtained from equations (15) to (17) and the kinetic parameters used were similar to those given by Swanda (1994).

As the slaker reactor was not insulated and the temperature of the reacting mixture was greater than the ambient temperature, heat flux occured from the reacting mixture to the environment. This heat loss was governed by an overall heat transfer coefficient, $\mathrm{U}$, that represented an equivalent thermal resistance $\left(R_{\mathrm{eq}}=1 / \mathrm{UA}\right)$, composed by association of three distinct thermal resistances, on the reaction mixture $\left(\mathrm{R}_{\text {int }}=1 / \mathrm{h}_{\text {int }} \mathrm{A}\right)$; on the wall of reactor $\left(R_{w}\right)$ and externally $\left(R_{e x t}=1 / h_{e x t} A\right)$, as Equation (15).

$$
\frac{1}{U A}=\frac{1}{h_{e x t} A}+\frac{e_{w}}{A_{l m} k_{w}}+\frac{1}{h_{\mathrm{int}} A}
$$

Wall thermal conductivity $\left(\mathrm{k}_{\mathrm{w}}\right)$ was taken from the literature, wall thickness $\left(\mathrm{e}_{\mathrm{w}}\right)$ and logarithmic averaged area $\left(\mathrm{A}_{\mathrm{Im}}\right)$ from design specifications. The internal heat-transfer coefficient by convection $\left(\mathrm{h}_{\text {int }}\right)$ was obtained from Equation (16), presented by Lydersen (1979), using physical properties of pure water because the reacting mixture was composed of a diluted solution.

$$
\frac{h_{\text {int }} D}{k}=C\left(\frac{\rho n D_{\text {agitator }}^{2}}{\mu}\right)^{2 / 3}(\operatorname{Pr})^{1 / 3}
$$

where $\operatorname{Pr}$ is the fluid Prandtl number; $D$ is the reactor inner diameter; $D_{\text {stirrer }}$ is the stirrer diameter; $\rho, \mu, k$ are density, viscosity and conductivity of the fluid and $n$ is the stirrer rotation in rps.

Heat dissipation to ambient occured by free convection from reactor walls to the surrounding air. Hence, the external heat transfer coefficient $\left(h_{\text {ext }}\right)$ was obtained from Equation (17), presented by Kreith (1973), which took into account Grashoff number (Gr) and Prandtl number.

$$
\frac{h_{e x t} D}{k}=0.13(G r \operatorname{Pr})^{1 / 3}
$$

Heat transfer coefficients were calculated from Equations (15), (16) and (17). External heat transfer coefficient is $h_{\mathrm{ext}}=6.28 \mathrm{~J} /\left(\mathrm{m}^{2}{ }^{\circ} \mathrm{C} \mathrm{s}\right)$ and, $\mathrm{h}_{\mathrm{int}}=1.9510^{5} \mathrm{~J} /\left(\mathrm{m}^{2}{ }^{\circ} \mathrm{C} \mathrm{s}\right)$. Then, the three thermal resistances related to the process were calculated: $\mathrm{R}_{\text {int }}=4.8910^{-6}{ }^{\circ} \mathrm{C} \mathrm{s} / \mathrm{J} ; \mathrm{R}_{\mathrm{W}}=2.3110^{-5}{ }^{\circ} \mathrm{C} \mathrm{s} / \mathrm{J}$ and $\mathrm{R}_{\mathrm{ext}}=2.5310^{-3}{ }^{\circ} \mathrm{C} \mathrm{s} / \mathrm{J}$, indicating that the heat transfer between the reactor walls and the ambient air was the limiting step ( $98.9 \%$ of $\mathrm{R}_{\text {eq }}$ ). Thus, $\mathrm{R}_{\mathrm{eq}}$ $\approx \mathrm{R}_{\mathrm{ext}}$ and $\mathrm{UA}=394.38 \mathrm{~J} /\left({ }^{\circ} \mathrm{C} \mathrm{s}\right)$. The values of the thermal and kinetics parameters used in simulations are shown in Table 1.

Table 1 - Parameters of the model

\begin{tabular}{cc}
\hline $\mathrm{UA}$ & $394.38 \mathrm{~J} /\left({ }^{\circ} \mathrm{C} \mathrm{s}\right)$ \\
\hline $\mathrm{k}_{2}$ & $5.5510^{-3} \mathrm{~s}^{-1}$ \\
$\mathrm{k}_{1,0}$ & $6.1810^{-2}\left(\mathrm{~m}^{3} / \mathrm{kg}_{\mathrm{Na} 2 \mathrm{O}}\right)\left(\mathrm{m}^{3} / \mathrm{kg}_{\mathrm{Ca}(\mathrm{OH}) 2}\right) \mathrm{s}^{-1}$ \\
$\mathrm{k}_{2,0}$ & $2.4110^{-5}\left(\mathrm{~m}^{3} / \mathrm{kg}_{\mathrm{Na} 2 \mathrm{O}}\right)^{2}\left(\mathrm{~m}^{3} / \mathrm{kg}_{\mathrm{Ca}(\mathrm{OH}) 2}\right) \mathrm{s}^{-1}$ \\
\hline
\end{tabular}




\section{RESULTS AND DISCUSSION}

The mathematical model was composed of seven ordinary differential equations, Equations (1) to (7), and Equation (9), two kinetic equations for Slaking and Causticizing reactions, Equations (13) and (14) and, additionally, Equation (12) to calculate the volumetric flow rate of limed liquor in the exit of reactor. This model was numerically solved by SDRIV2 subroutine available in Kahaner et al (1989), with initial conditions presented in Table 2. The reactor simulation, on the first instants of simulation, was not real; it was a hypothetical situation that resulted in a real condition of operation in steady-state conditions. The operational conditions and reactor dimensions used in model simulations, are shown in Table 3. According to Figs. 2, 6 and 7, the dynamic model satisfactorily described the steady-state behaviour of the industrial slaker reactor, with respect to the temperature, active alkali (AA) and total titratable alkali (TTA), measured at exit of reactor in steady- state conditions, without the need of further parameter adjustment.

The concentrations of $\mathrm{NaOH}, \mathrm{Na}_{2} \mathrm{CO}_{3}, \mathrm{Na}_{2} \mathrm{~S}$ and mass of $\mathrm{CaO}$ and $\mathrm{CaCO}_{3}$ reached steady-state in approximately 15 minutes, except mass of $\mathrm{Ca}(\mathrm{OH})_{2}$ that took about 40 minutes, according to Fig 3, 4 and 5. The concentration of $\mathrm{Na}_{2} \mathrm{CO}_{3}$ and the mass of $\mathrm{CaO}$ showed a significant decrease initially, tending to constant values of 50.62 $\mathrm{kg}_{\mathrm{Na} 2 \mathrm{CO} 3} / \mathrm{m}^{3}$ and $379.84 \mathrm{~kg}$ of $\mathrm{CaO}$. While the concentration of $\mathrm{Na}_{2} \mathrm{CO}_{3}$ and mass of $\mathrm{CaO}$ decreased in the system, the concentration of $\mathrm{NaOH}$ and mass of $\mathrm{CaCO}_{3}$ naturally increased in the same proportion, because they were products of the causticizing reaction, tending to values of $85.54 \mathrm{~kg} / \mathrm{m}^{3}$ and $3772.1 \mathrm{~kg}$, respectively, in steady-state conditions (Figs. 3 and 4). Contrary to the behaviour mentioned above, the $\mathrm{Na}_{2} \mathrm{~S}$ did not react, and its concentration was practically constant at $31.40 \mathrm{~kg} / \mathrm{m}^{3}$ during the entire simulation.

Table 2 - Model initial conditions

\begin{tabular}{cc}
\hline $\mathrm{C}_{\mathrm{a}}$ & $145.30 \mathrm{~kg} / \mathrm{m}^{3}$ \\
\hline $\mathrm{C}_{\mathrm{b}}$ & $7.69 \mathrm{~kg} / \mathrm{m}^{3}$ \\
$\mathrm{C}_{\mathrm{c}}$ & $29.79 \mathrm{~kg} / \mathrm{m}^{3}$ \\
$\mathrm{~m}_{\mathrm{d}}$ & $2639.5 \mathrm{~kg}$ \\
$\mathrm{~m}_{\mathrm{e}}$ & $0.0 \mathrm{~kg}$ \\
$\mathrm{~m}_{\mathrm{f}}$ & $0.0 \mathrm{~kg}$ \\
$\mathrm{~m}_{\mathrm{g}}$ & $342.3 \mathrm{~kg}$ \\
$\mathrm{~T}$ & $88.0^{\circ} \mathrm{C}$ \\
\hline
\end{tabular}

Table 3 - Dimensions of Slaker reactor and operation conditions

\begin{tabular}{cc}
\hline Total volume & $41.60 \mathrm{~m}^{3}$ \\
\hline Internal diameter of reactor & $4.80 \mathrm{~m}$ \\
Height of reactor & $3.19 \mathrm{~m}$ \\
Agitator diameter & $1.75 \mathrm{~m}$ \\
Agitation speed & $0.93 \mathrm{rps}$ \\
Heat transfer area & $62.83 \mathrm{~m}^{2}$ \\
Green liquor flow rate & $3.8910^{-2} \mathrm{~m}^{3} / \mathrm{s}$ \\
Green liquor temperature & $88.0^{\circ} \mathrm{C}$ \\
Lime addition rate & $2.79 \mathrm{~kg} / \mathrm{s}$ \\
Lime temperature & $300.0^{\circ} \mathrm{C}$ \\
Lime availability & $88.52 \%$ \\
Ambient temperature & $20.0^{\circ} \mathrm{C}$ \\
\hline
\end{tabular}




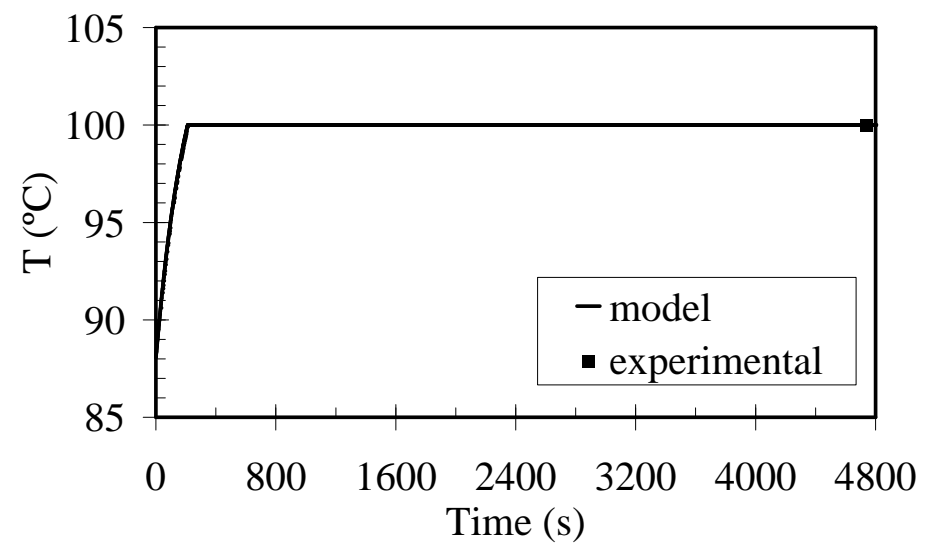

Figure 2 - Temperature as a function of time

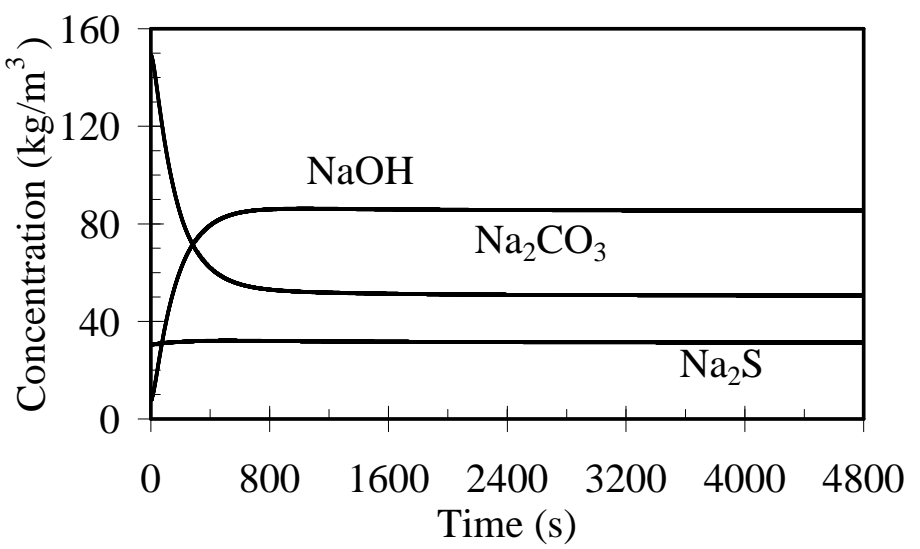

Figure 3 - Concentration as a function of time.

While the mass of inert solids in the reactor stayed practically unchanged along the time, and was equal to $337 \mathrm{~kg}$, the mass of $\mathrm{Ca}(\mathrm{OH})_{2}$ grew quickly initially, reaching a maximum of $300 \mathrm{~kg}$ and decreasing slowly soon after reaching the value of $149.69 \mathrm{~kg}$ at steady-state (Fig. 5). This behaviour revealed that initially the rate of generation of $\mathrm{Ca}(\mathrm{OH})_{2}$ by the Slaking reaction was higher than the rate of consumption of this component by the Causticizing reaction; however, this was reversed over time.

The active alkali (AA) presented a fast growth in the first minutes, due to the increased concentration of $\mathrm{NaOH}$ in the reactor, and it reached the concentration of steady-state condition in $91.15 \mathrm{~kg} / \mathrm{m}^{3}$ in the first 15 minutes (Fig. 6), while the total titratable alkali (TTA) stayed practically constant $\left(120.78 \mathrm{~kg} / \mathrm{m}^{3}\right.$ in steady-state condition) for the simulated period (Fig. 7). This behaviour was expected since for each molecule of consumed $\mathrm{Na}_{2} \mathrm{CO}_{3}$, two molecules of $\mathrm{NaOH}$ were formed, consequently there was a compensation between the mass of $\mathrm{Na}_{2} \mathrm{O}$ that was generated and the one that was consumed in the forms of $\mathrm{NaOH}$ or $\mathrm{Na}_{2} \mathrm{CO}_{3}$.

At the first instant of simulation, the temperature of the reactor quickly increased because of the development of the strongly exothermic slaking reaction, taking around 3.5 minutes to reach the boiling temperature of the reacting mixture, 100 
${ }^{\circ} \mathrm{C}$, and stayed constant until the end of the simulated period (Fig. 2).

Although the volumetric flow rate of limed liquor in the exit of the reactor (q) was composed of five different terms: $\mathrm{q}_{\mathrm{CaCO} 3}, \mathrm{q}_{\mathrm{H} 2 \mathrm{O}}, \mathrm{q}_{\mathrm{Ca}(\mathrm{OH}) 2}, \mathrm{q}_{\mathrm{CaO}}$ and $\mathrm{q}_{\text {inerts}}$, only the terms corresponding to the water and to the calcium carbonate, exerted significant influence on this flow, corresponding to 94.2 and $5.4 \%$ of the total, respectively. Because of that the behaviour of $q$ was determined by the term corresponding to the water volumetric flow rate $\left(\mathrm{q}_{\mathrm{H} 2 \mathrm{O}}\right)$. On the other hand, when the exit volumetric flow rate, $\mathrm{q}$, was compared to the feeding volumetric flow rate, $\mathrm{q}_{0}$, a small difference between them was observed at steadystate: $1.3 \%$ in relation to $\mathrm{q}_{0}$ (Fig. 8).

Owing to the development of the causticizing reaction, the volumetric flow rate of calcium carbonate $\left(\mathrm{q}_{\mathrm{CaCO} 3}\right)$ quickly increased and reached the maximum value of $2.1210^{-3} \mathrm{~m}^{3} / \mathrm{s}$, in the first twelve minutes (Fig. 8). Simultaneously, the volumetric flow rate of water $\left(\mathrm{q}_{\mathrm{H} 2 \mathrm{O}}\right)$ also reached the maximum value of $3.7110^{-2} \mathrm{~m}^{3} / \mathrm{s}$, being $4.6 \%$ smaller than the feed $\left(3.8910^{-2} \mathrm{~m}^{3} / \mathrm{s}\right)$. However, $\mathrm{q}_{\mathrm{H} 2 \mathrm{O}}$ suffered great oscillation in the first instants due to the high consumption of water by the slaking reaction $\left(\mathrm{q}_{\mathrm{r} 2}\right)$ and by the evaporation $\left(\mathrm{q}_{\text {evap}}\right)$, and it reached steady-state after 210 seconds (Fig. 9). Both, $\mathrm{q}_{\text {evap }}$ and $\mathrm{q}_{\mathrm{r} 1}$ showed maximum values of $2.78 \times 10^{-3}$ and $3.4510^{-3} \mathrm{~m}^{3} / \mathrm{s}$, respectively in the first 210 seconds, and decreased slowly until they reached constant values of $1.15 \times 10^{-3}$ and $6.42 \times 10^{-4} \mathrm{~m}^{3} / \mathrm{s}$, respectively after 900 seconds.

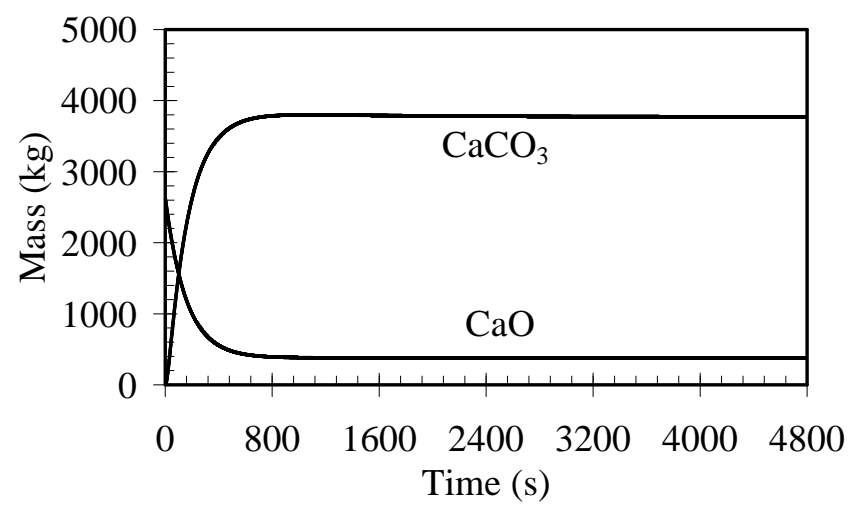

Figure 4 - Mass of $\mathrm{CaO}\left(\mathrm{m}_{\mathrm{d}}\right)$ and $\mathrm{CaCO}_{3}\left(\mathrm{~m}_{\mathrm{f}}\right)$ as a function of time.

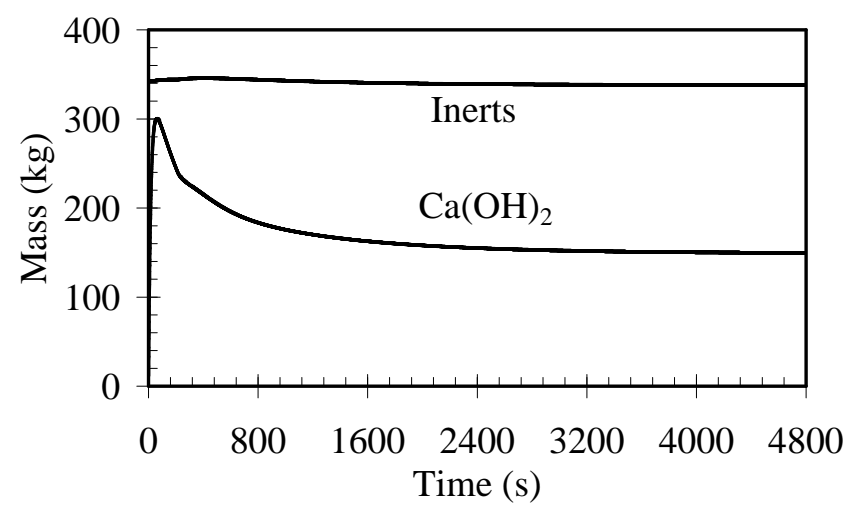

Figure 5 - Mass of $\mathrm{Ca}(\mathrm{OH})_{2}\left(\mathrm{~m}_{\mathrm{e}}\right)$ e inert solids $\left(\mathrm{m}_{\mathrm{g}}\right)$ as a function of time. 


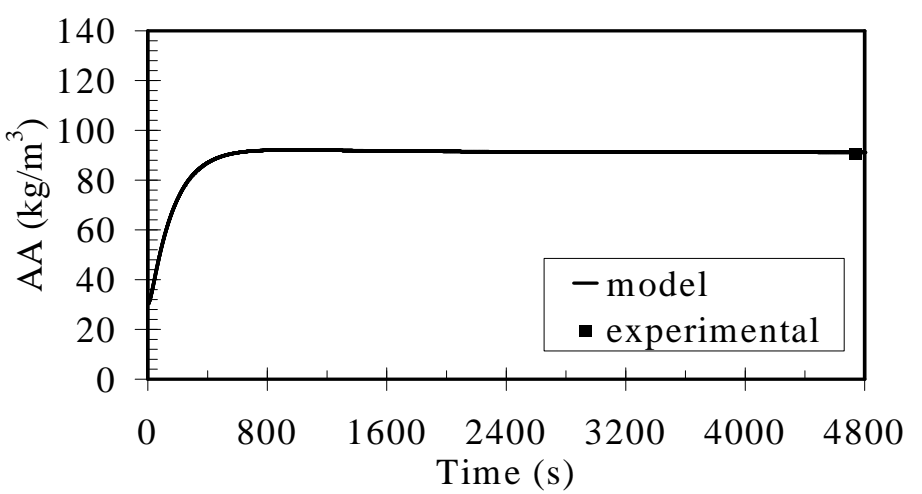

Figure 6 - Active alkali (AA) as a function of time.

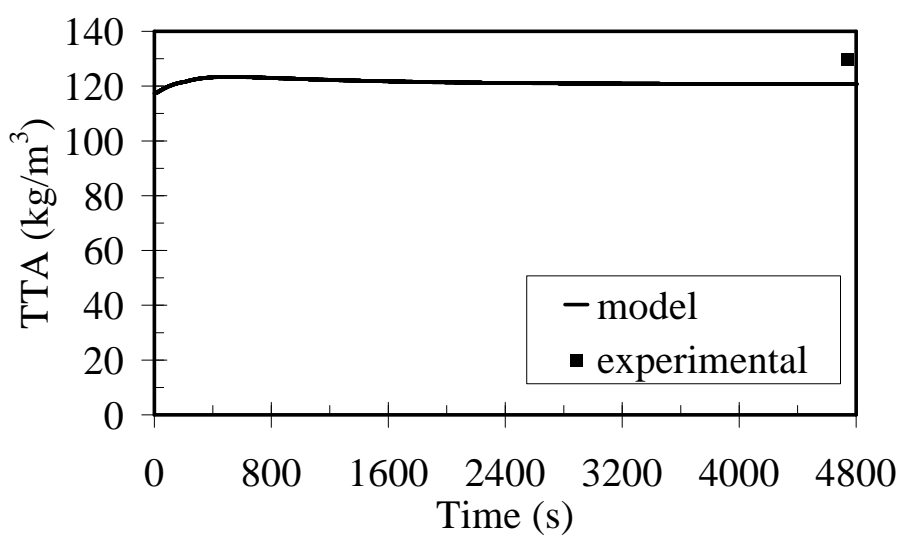

Figure 7 - Total titratable alkali (TTA) as a function of time.

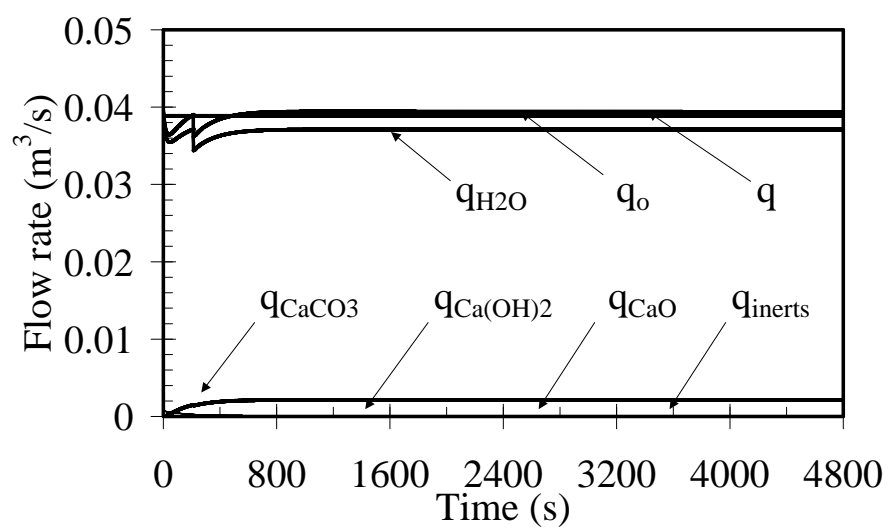

Figure 8 - Volumetric flow rates as a function of time. 


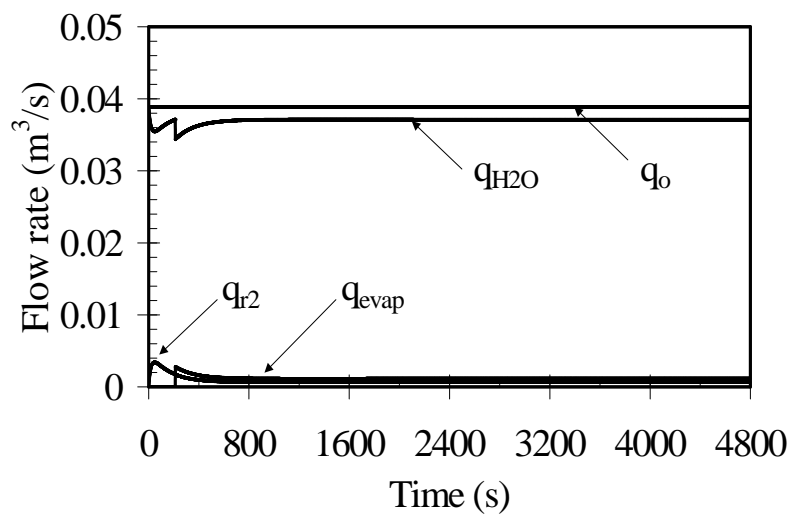

Figure 9 - Volumetric flow rate of water as a function of time, $\left(q_{H 2 O}=q_{0}-q_{r 2}-q_{\text {evap }}\right)$

\section{ACKNOWLEDGEMENTS}

The authors thank the State University of Maringá / DEQ and Klabin Paraná Papéis Telêmaco Borba - PR for the technical and financial support.

\section{RESUMO}

Foi desenvolvido e testado um modelo dinâmico do reator de apagamento do sistema de caustificação da Klabin Paraná Papéis, responsável pela geração do licor branco utilizado na planta. O modelo contempla perdas de água por evaporação e por reação química e apresentou boa concordância com dados industriais de álcali ativo, álcali total titulável e temperatura, sem a necessidade de ajuste de nenhum parâmetro. Os resultados obtidos a partir de simulações revelam que o consumo de água pela reação de apagamento, bem como pela evaporação, exercem uma influência significativa sobre a vazão volumétrica na saída do reator, impondo uma diminuição de $4,6 \%$ sobre o teor de água na corrente de saída do reator em relação à alimentação.

\section{REFERENCES}

Andreola, R. (2001), Modeling, Simulation and Analysis of Klabin Paraná Papéis Causticizing Reactor System. M.S. Thesis (in Portuguese), State University of Maringá, Maringá, Brazil.

Hypponen, O. and Luuko A. (1984), The residence time distributions of liquor and lime mud flows in the recausticizing process. Tappi Journal, 67(7), 46-48.

Kreith, F. (1973), Principles of Heat Transfer. Intext Press, New York.

Kahaner, D. Moler, C. Nash, S. (1989), Numerical methods and software. Prentice Hall Series in Computational Mathematics, New Jersey.

Lydersen, L. A. (1979), Fluid flow and heat transfer. John Wiley and Sons, New York.

Swanda, A.P.(1994), Process modeling and control system evaluation for the pulp and paper recausticizing process. M.S. Thesis, University of California, USA.
Received: May 05, 2005; Revised: March 08, 2006; Accepted: October 18, 2006. 
PÁGINA

EM

BRANCO 